\title{
ХАРАКТЕРИСТИКА ЛЕКСИКО-СЕМАНТИЧЕСКИХ ГРУПП РУСИЗМОВ В ЯЗЫКЕ ТУНДРОВЫХ ЮКАГИРОВ: ТЕХНИКА
}

\author{
к.филол.н. Курилова С. Н. \\ Россия, г. Якутск, Институт гуманитарных исследований и проблем малочисленных народов \\ Севера СО РАН
}

DOI: https://doi.org/10.31435/rsglobal_wos/31102019/6745

\section{ARTICLE INFO}

Received: 20 August 2019

Accepted: 16 October 2019

Published: 31 October 2019

\section{KEYWORDS}

Tundra Yukaghir,

Yakut,

Russian,

transfer,

thematic classification,

phonetic adaptation.

\begin{abstract}
The Yukaghirs is one of the ancient aboriginal peoples of the northeastern Siberia. Nowadays there are two local Yukaghir groups. The Tundra Yukagirs live in Lower Kolyma river and the Forest Yukaghirs dwell in Upper Kolyma. Their languages are common in sintax, but different in lexicon and phonetics as a result of historic established contacts with other newcomers. The paper is devoted to lexical transfer as a result of the language contacts as one of the most actual in the modern linguistics and purely studied themes in Yukagir studies. According to last research of the foreign lexicon in Yukaghir there is appr. 800 Russian words in Tundra Yukaghir, of which 170 entered via Yakut. The author classifies, characterizes and analyzes the direct and indirect Russian words within the group titled as "Technics" from functional and formal assimilative points of view.
\end{abstract}

Citation: Курилова С. Н. (2019) Kharakteristika Leksiko-Semanticheskikh Grupp Rusizmov v Yazyke Tundrovykh Yukagirov: Tekhnika. International Academy Journal Web of Scholar. 10(40), doi: 10.31435/rsglobal_wos/31102019/6745

Copyright: (C) 2019 Курилова С. Н. This is an open-access article distributed under the terms of the Creative Commons Attribution License (CC BY). The use, distribution or reproduction in other forums is permitted, provided the original author(s) or licensor are credited and that the original publication in this journal is cited, in accordance with accepted academic practice. No use, distribution or reproduction is permitted which does not comply with these terms.

Введение. Многовековое проживание юкагиров - автохтонов северо-востока Сибири - с иноязычными народами-пришельцами несомненно и неизбежно привело к проникновению в их язык новых слов для обозначения новых реалий, с которыми юкагиры до этого не были знакомы. Особенно большой пласт иноязычной лексики составляют лексические единицы, языкомисточником которых является русский язык. Рассматриваемые в данной статье русизмы являются результатов языковыХ контактов второго, так называемого советского периода (1920-е гг. XX в. кон. XX в.), характеризующегося регулярностью, большим составом заимствованного лексического материала, который практически не подвергался фонетической адаптации, и изменениями в морфосинтаксисе слабого языка в результате билингвизма большинства или всех носителей [5: 237; 15]. В этот период исследователи усматривают постепенное утрачивание юкагирским языком тех специфических черт русизмов, которые были свойственны иноязычным заимствованиям первого периода (сер. XVII - кон. XVIII вв.). Т.е. если в первом периоде слова из русского языка (также через язык-посредник) усваивались юкагирами по необходимости, то во втором - юкагиры вынуждены были переходить на языки окружения, главным образом на якутский [5: 237, 242]. При этом могло происходить одновременное заимствование как напрямую из языка- источника, так и через языкпосредник, что было обусловлено сложившейся языковой ситуацией, когда титульным языком страны в связи с новым курсом в национальной политике, провозглашенным в конце 1940-х гг. был провозглашен русский, а позднее наряду с ним и якутский как государственный язык Якутии.

Результаты исследования. В юкагирском языке в настоящее время выделено 27 тематических групп русизмов, одна из которых включает лексические переносы из русского языка как прямого, таки опосредованного характера. 
В предлагаемой статье представлен обзор русизмов, обозначающие различные виды транспорта, технику, используемую в сельском хозяйстве, а также части машин, включая топливо. Здесь же мы предлагаем рассматривать термины, обозначающие средства связи и другие технические аппараты бытового использования.

(1) Воздушный транспорт

Аракиэтэ аракиэта 'ракета' < як. аракиэта, аракыата 'ракета' [2: 533; 12: 225] < рус. ракета. Напр.: Тэньи аракиэталэ кэчинутэм, мэр өгэтэнутэм. ‘Сюда ракету принесут и поставят’ [10: 47]

Йарапалаан, йэрэпэлэн 'аэроплан; самолет' [7: 147; 5: 247; 16: 8] < рус. аэроплан. Напр.: Йарапалаанлэк чэнгурурэн тэтул пурэт йуочиинунуй. 'На самолете (зд. аэроплане) пролетая, на тебя сверху смотрим’ [8: 11]

Пэртэльиэт, вертолём 'вертолет' < рус. вертолет. Напр.: Эгуойигир чаай ин йуоқачэли пэртэльиэтлэн сэругиэл. 'Утренний чай только закончили (пить) - вертолет начал садиться' [7: 455]

Самолёm 'самолет' < рус. самолет. Напр.: Самолет - мэр амуч, массиина - мэр амуч, тан мэт аньмил йаунээйдэБэт амуолги мэт мэ курильиин! 'Самолет - хорошо, машина хорошо, а олень по сравнению всеми ими еще лучше, я знаю!’ [9: 29]

Самальуот 'самолет' [5: 247; 6: 98] < як. самадьыат, самолуөт, сөмөлуөт 'самолет' [11: 2059; 13: 313; 12: 171, 228] < рус. самолет [3: 525]. Напр.: Исэ-льиэ мит самальуот эт кэлут. 'Ну, возможно, наш самолет не прилетит' [6: 240]

(2) Наземный транспорт

Автобус 'автобус' < рус. автобус. Напр.: Тан Чиэрискэй тадаатэ Андэруускэ ньанальэруульан автобуслэк чии эурэни. 'А между Черским и Андрюшкино на автобусе (букв. автобусом) люди ездят’ [1: 16]

Актанабил 'автомобиль' < рус. автомобиль. Напр.: Таатльэллэдэ мэ кэжэчэли: йоходилэлэк, актанабилэк. 'Потом поехали на лошадях, на автомобиле’ [4: 261]

Вездеход 'вездеход’ < рус. вездеход. Напр.: Вездеход аарэйдаБанэ мэр аарэйнулльэнь, чақадьэйдақанэ жаaй мэ көчэгэйнулльэнь. 'Когда вездеход останавливался, останавливалась (собака), когда двинется, тоже бежала’ [7: 536]

Машина машинэ 'машина (как средство передвижения или производства); швейная машинка' [18: 48, 80; 16: 260] < рус. машина. Напр.: Көнмэ илэн чии машинэ чобунэй индьииБа пиисиэнунна - тађи эл амуонун. 'Другие оленные люди начинают обматывать (обрезанные ушки оленят) тонкой машинной ниткой - так (букв. то) не хорошо бывает’ [17: 17]; Пөмниир чиилэн, сақанэнул, мираанунул, машинапэ пойуолни. 'Вокруг людей, сидящих, идущих, машин много' [9: 29]

Масина масинэ, массиина массиинэ 'машина (как средство передвижения или производства)' [18:48,80; 16:260] < як. мас(с)ыына ‘машина; машинный’ [13:236; 12:211]< рус. машина. Напр.: Энускуриэрэ чалдьэлэк эл энускуриэ, йашнэр масиналэк энускуриэни. 'Если работают (букв. работая), руками не работают, все машиной делают (они)' [4:262]; Идьирэ, хандьэмэдэ, моорхуонь массиинэлэн пойуойнэн эуриэл. 'Теперь зимой только лишь машина помногу раз ездит' [9:29]

Пуойэст 'поезд’ < рус. поезд. Напр.: Эгуойиэ пуойэст Ленингратинь кэюэйтэй. ‘Завтра поезд в Ленинград уйдет' [4: 261]

Снегоход 'снегоход’ < рус. снегоход. Напр.: Тидаa, тун ньиэдьилэ ньимэлэсуй көдэ искуолэђэ эуриэнудэқа, самолет, вертолет, вездеход, мотуорнай луодка, снегоход нодьэрукунпэ эульэну. 'В то время, когда автор этого рассказа (букв. этот рассказ пишущий человек) в школу ходил, не было самолетов, вертолетов, вездеходов, моторных лодок, снегоходов и тому подобного’ [9: 35]

Такси 'такси' < рус. такси. Напр.: Такси хадаa аарэйнун? 'Где стоянка такси (букв. такси где останавливается)?’ [1: 16]

Транспор 'транспорт' < рус. транспорт. Напр.: Хуодэбандьэ транспорлэк тит эжриэнунмут? ‘Каким транспортом (видом транспорта) вы ездите?’ [1: 16]

(3) Водный транспорт

Л(у)одка 'лодка' < рус. лодка. Напр.: Уури тэт жаай чамбиичэк, луодка лажйэги оочэк. 'Или ты тоже иди помогать, воды из лодки иди вычерпывай' [7: 348]

Mот(у)орка 'моторка' < рус. моторка 'моторная лодка'. Напр.: Мотуоркалэн эшриэнул орири, титэбандьэ эбэкиэқа, титэбандьэ сукун ньаарчидьэБа! 'Моторка ходит как ни в чем не бывало, в такую сырость, в такую непогоду!' [7: 578]

Парахуоm nэрэхот 'пароход’ < рус. пароход. Напр.: Таатльэллэдэ пэрэхотлэк мэ кэвэчэли Льиэнэқан. 'А еще на пароходе поехали по (реке) Лене' [4: 261]

Шлюпка 'шлюпка' < рус. шлюпка. Напр.: Шэдэкэй эньиэ нимэБэт пулгээйрэлэк ичуом: шлюпка-өлдьэђэ Шэдэкэй саБанэл, тан хальархаапэ тудэ пөмниир саБанэрэн, анмэ мэ нэмэлэ 
ньиэдьинул дитэ банни. 'Мама Ведекея, из дома выйдя, видит: в шлюпке-лодке Ведекей сидит, а чайки, вокруг него сидя, прямо-таки что-то рассказывают как будто’ [9: 42]

(4) Сельскохозяйственная техника

Трактор 'трактор' < рус. трактор. Напр.: Таат уудэк гаражсхэ чаБадьэй; тракторпэлэ ремоннам. 'Так все время в гараже работал; тракторы ремонтировал' [10: 57]

(5) Детали техники

Мотор 'мотор' < рус. мотор. Напр.: «Мэтханэ мотор кэурэйтэм!» - мондэлэк, мунғайдьии моторлэ сэругэттэрэйм!... ' «Мне мотор унесет!» - сказав (так), женщина мотором грохнула' [10: 32]

Мотуор 'мотор' [5: 247] < як. мотуор 'мотор' [13: 242; 12: 172] < рус. мотор. Напр.: Мотуорньэй чии ханьинэн эБадуолБан эл уунунну, чумдамунги моойнуннумлэ. 'Люди с моторной лодкой (букв. мотор имеющие люди) никогда вдоль берега не идут, стрежня держатся’ [7: 585]

Руль 'руль' < рус. руль. Напр.: Нимэнгин пэнгэйлэханэ амаа мэтханэ тудэ жаль саБанасчиинунум - мотор руль киинунум. 'Когда домой вернулся, отец меня рядом с собой ненадолго садил - руль мотора давал’ [10: 57]

(6) Названия топлива

Бензин 'бензин' < рус. бензин. Напр.: Эйк угунэн льиэ, эл моойсаанубэрукунэк! Тиэн йуку хостиэ анмэльэй бензинлэн... 'Действительно, не подлежащий сдаче на содержание (дом)! Эта маленькая комнатка просто в бензине (зд. заполнена канистрами бензина)...' [7: 258]

Газ 'газ' < рус. газ. Напр.: Титтэл хайльпэлэ тадаат «газ» нодьэрукунэ жанчинуннаа. 'Они (зд. геологи) камни (зд. полезные ископаемые) и «газ» ищут' [10: 9]

(7) Средства связи

Автомат 'автомат' < рус. автомат (телефонная будка). Напр.: Москваньэн автоматлэк ньиэдьиччэк. 'С Москвой по автомату переговори' [1: 17]

Араадьиша 'радио' [5: 247; 6: 26, 98] < як. раадыйа, араад(ь)ыйа 'радио' [2: 519; 13: 300; 12: 224] < рус. радио. Напр.: Мэт араaдьиwa эл мондьиэнундьэн алБадьаa waаwачэд-аруу эл курильиийэн. 'Я радио не слушаю, слишком уж по-русски не знаю' [6: 220]

Арасия, рация 'рация' < рус. рация. Напр.: ИстаадопэБа арасиялэн. 'В стадах - рации (есть)' [14: 166]

Телеграф 'телеграф' < рус. телеграф. Напр.: Мэт телеграфнинь амдур ат ууйэн. 'Мне на телеграф срочно нужно пойти' [1: 17]

Телефон 'телефон' < рус. телефон. Напр.: Арэй телефонлэн сэругиэл. 'Вдруг зазвонил телефон' [7: 455]

Tелепуон 'телефон' [тильипуон - 5: 247, 255] < як. түлүпүөн, төлү(п)пуөн, телефон 'телефон; телефонный' [13: 381; 12: 171, 233] < рус. телефон. Напр.: Телепуон сэругээйтэй, өлкиэйэн. ‘Зазвонит (букв. загремит), бегу (чтобы успеть ответить на звонок)’ [14: 164]

(8) бытовая техника и другое оборудование

Маннитофуон 'магнитофон' < рус. магнитофон. Напр.: «Эньиэ, малаа: маннитофуоньа йахтэк!» Эньиэ мэ ньиэдьим, мэ йахтэй. “«Мама, ну же: в магнитофон пой (зд. идет речь о записи голоса матери на ленточную кассету)!» Мама рассказала, спела' [9: 33]

Телевизор 'телевизор' < рус. телевизор. Напр.: Пэлдудиэпэ нимэБа саБанаанунни, телевизорлэн ичуонуннумлэ. 'Старики дома сидят, телевизор смотрят' [1:28]

Фomoannapam 'фотоаппарат' < рус. фотоаппарат. Напр.: Мэт фотоапnарат маархуонь эл онунббрульа ат амуч. 'Хорошо бы мой фотоаппарат только не намочить (букв. мой фотоаппарат только не в намокании бы есть хорошо)' [7: 344]

У русизмов мы можем отметить следующие особенности формальной адаптации.

1. Фонетико-графическое освоение прямых русизмов

- в системе вокализма:

Субституция гласных: a > aа (рус. аэроплан > юк. йарапалаан), а > э (рус. аэроплан $>$ юк. йэрэпэлэн, рус. машина $>$ юк. машинэ, рус. пароход $>$ юк. пэрэхот), е $>$ э (рус. вертолёт $>$ юк. пэртэльиэт), е > йэ (рус. поезд $>$ юк. пуойэст), ё > иэ (рус. вертолёт $>$ юк. пэртэльиэт), o > a (рус. аэроплан $>$ юк. йарапалаан, рус. автомобиль $>$ юк. актанабил, рус. пароход $>$ юк. парахуот), o > э (рус. аэроплан > юк. йэрэпэлэн, рус. вертолёт > юк. пэртэльиэт, рус. пароход > юк. пэрэхот), о > уо (рус. лодка > юк. луодка, рус. магнитофон $>$ юк. маннитофуон, рус. поезд > юк. пуойэст, рус. пароход > юк. парахуот).

Субституция дифтонгов: аэ > йа (рус. аэроплан > юк. йарапалаан), аэ > йэ (рус. аэроплан $>$ юк. йэрэпэлэн).

Наращение гласных: ø > a, э (рус. рация > юк. арасия, рус. аэроплан > юк. йарапалаан, йэрэпэлэн). 
- в системе консонантизма:

Субституция согласных: в > к (рус. автомобиль $>$ юк. актанабил), в $>$ п (рус. вертолёт $>$ юк. пэртэльиэт), г $>$ н (рус. магнитофон $>$ юк. маннитофуон), д $>$ т (рус. поезд $>$ юк. пуойэст, рус. пароход $>$ юк. парахуот, пэрэхот), $3>$ c (рус. поезд $>$ юк. пуойэст), л $>$ ль (рус. вертолёт $>$ юк. пэртэльиэт), ль $>$ л (рус. автомобиль $>$ юк. актанабил), м $>$ н (рус. автомобиль $>$ юк. актанабил), н > н (рус. аэроплан > юк. йэрэпэлэн), с > ц (рус. рация > юк. арасия).

Усечение согласных: т $>\varnothing$ (рус. транспорт $>$ юк. транспор).

2. Фонетико-графическое освоение опосредованных русизмов

- в системе вокализма:

Субституция гласных: a $>$ э (рус. ракета $>$ як. аракиэта $>$ юк. аракиэтэ, машина $>$ як. массыына $>$ юк. массиинэ $\sim$ масинэ), o $>$ a (рус. самолёт $>$ як. самолуөт $>$ юк. самальуот), уө $>$ уо (рус. самолёт $>$ як. самолуөт $>$ юк. самальуот), ү $>$ е (рус. телефон $>$ як. түлүпүөн $>$ юк. телепуон), үө $>$ уо (рус. телефон $>$ як. түлүпүөн $>$ юк. телепуон), ы $>$ и (рус. радио $>$ як. араадьыйа $>$ юк. араадьиша), ыы $>$ ии (рус. машина $>$ як. массыына $>$ юк. массиина массиинэ), ыы $>$ и (рус. машина $>$ як. массыына $>$ юк. масина $\sim$ масинэ).

Субституция согласных: й $>$ w (рус. радио $>$ як. араадьыйа $>$ юк. араадьиwa), л $>$ ль (рус. самолёт > як. самолуөт > юк. самальуот).

Выводы. Таким образом, в корпусе юкагирского языка зарегистрировано 29 русизмов, обозначающих воздушный транспорт (4), наземный транспорт (8), водный транспорт (4), сельскохозяйственную технику (1), детали техники (2), названия топлива (2), средства связи (5) и бытовую технику (3). Выявлено одновременное наличие лексем для обозначения одной и той же реалии как на русском, так и якутском языках (самолёт и самальуот, машина машинэ и массиина массииннэ, мотор мотуор, телефон телепуон). Шесть русизмов проникли в юкагирский язык в якутской «обработке» (араaдьиwa, аракиэтэ, массиина, мотуор, самальуот, телепуон). 13 русизмов вошли в юкагирский язык без формальных изменений (автобус, снегоход, шлюпка, руль, телевизор и др.), в то время как остальные, включая часть якуто-опосредованных, подверглись формальной адаптации - чередованию гласных и согласных звуков, наращению гласных и усечению согласных.

Сокращения: букв. - буквально, зд. - здесь, напр. - например, рус. - русский язык, юк. - юкагирский язык, як. - якутский язык.

\section{ЛИТЕРАТУРА}

1. Атласов Е.И., Курилов Г.Н. Русско-юкагирский разговорник. - Якутск: Розовая чайка, 1992. - 32 с.

2. Афанасьева П.С., Харитонова Л.Н. Русско-якутский словарь. - М.: Советская энциклопедия, 1968. - 720 с.

3. Аникин А.Е. Этимологический словарь русских заимствований в языках Сибири. - Новосибирск: Наука, 2003. - 788 с.

4. Крейнович Е.А. Юкагирский язык: монография. - М.-Л.: АН СССР, 1958. - 288 с.

5. Курилов Г.Н. Лексикология современного юкагирского языка (развитие лексики и роль в нем якутского языка): монография. - Новосибирск: Наука, 2003. - 288 с.

6. Курилов Г.Н. Современный юкагирский язык: учебное пособие. - Якутск: Офсет, 2006. - 280 с.

7. Курилов Г.Н. Юкагирско-русский словарь. - Новосибирск: Наука, 2001. - 608 с.

8. Курилов И.И. Напевы волн озера Улуро. - Якутск: Северовед, 1999. - 44 с.

9. Курилов Н.Н. Литературное чтение 4 класс: учебное пособие на юкагирском языке (тундренный диалект) для общеобраз. учрежд. - СПб.: Алмаз-Граф, 2013. - 96 с.

10. Курилов Н.Н. Чуннул кинигэ. 3 класснинь: книга для чтения на юкагирском языке. - Якутск: $1994 .-60$ с.

11. Пекарский Э.К. Словарь якутского языка [Электрон. ресурс]. - Л.: Академия наук СССР, 1959. T.2. Режим доступа: http://sakhatyla.ru/books/pekarskiy-2/482

12. Слепцов П.А. Русские лексические заимствования в якутском языке: послереволюционный период: монография. - М.: Наука, 1975. - 256 с.

13. Слепцов П.А. Якутско-русский словарь. - М.: Советская энциклопедия, 1972. - 608 с.

14. Kurilov N. Tales from my mother Anna Kurilova. Эньиэ, Анна Курилова ньиэдьилпэ. Рассказы матери Анны Куриловой / С. Ode (ed.). - Amsterdam: Uitgeverij Pegasus, 2012. - 270 p.

15. Matić D. Russian influence on the Kolyma Yukaghir morphosyntax / D. Matić // Sprachkontakt, synchron und diachron. In A. Casaretto, S. Kutscher (eds.). - Aachen: Shaker, 2008. - P. 93-124.

16. Nikolaeva I.A. A historical dictionary of Yukaghir. - Berlin, New York: Mouton de Gruyter, 2006. - 500 p.

17. Struchkova A. Various tales for the Yukaghir children. Ньиномиэйэ ньиэдьилпэ шадудуорпиэнь. Разные рассказы юкагирским детям / C. Ode (ed.). - Fürstenberg / Havel: Kulturstiftung Sibirien, 2016. - 92 p.

18. Veenker W. Tundrajukagirisches wörterverzeichnis zusammengestellt von Wolfgang Veenker // Opuscula Sibirica 1. - Hamburg: Universität Hamburg, 1989. - 83 p. 